\title{
Pengaruh Perubahan Harga Bahan Bakar Minyak Terhadap Investasi Saham Perusahaan Transportasi Darat
}

\author{
Nur Anisah ${ }^{1}$, Lilik Pujiati ${ }^{2}$, Dian Sulistyo Widiarti ${ }^{3}$ \\ STIE PGRI Dewantara Jombang \\ nanisasa47@yahoo.com²,lilik.pujiati@yahoo.com,wiwid.sulis@yahoo.com ${ }^{1}$
}

Diserahkan: 5 Januari 2017, Diterima: 7 April 2017

\begin{abstract}
This study aims to determine whether there are significant differences abnormal return and trading volume activity on ground transportation company shares listed on the Indonesia Stock Exchange before and after the announcement of the reduction in fuel prices on April 1, 2016. The analysis method used in this study is event study, The research period for 14 days around the announcement date, ie 7 days before and 7 days after the announcement of the announcement. The population used in this study is a transport company listed in Indonesia Stock Exchange sectoral index. Sample selection is done by purposive sampling method and sample obtained in this study amounted to 10 ground transportation company. Data analysis technique using Kolmogorov Sminorv test and Paired Sample t-test. The results of this study indicate that there are no significant differences in abnormal stock returns before and after the announcement of the reduction in fuel prices. But there are significant differences in the stock trading volume activity before and after the announcement of the reduction in fuel prices.
\end{abstract}

Keywords: Announcement decline in BBM, Abnormal Return, Trading Volume Activity, Event Study

\begin{abstract}
abstrak
Penelitian ini bertujuan untuk mengetahui apakah terdapat perbedaan yanng signifikan abnormal return dan trading volume activity saham pada perusahaan transportasi darat yang terdaftar di Bursa Efek Indonesia sebelum dan sesudah pengumuman penurunan harga BBM pada tanggal 1 April 2016. Metode analisis yang digunakan dalam penelitian ini adalah event study.Periode penelitian yang digunakan selama 14 hari di sekitar tanggal pengumuman, yaitu 7 hari sebelum pengumuman dan 7 hari sesudah pengumuman.Populasi yang digunakan dalam penelitian ini adalah perusahaan transportasi yang terdaftar dalam Indeks sektoral Bursa Efek Indonesia.Pemilihan sampel dilakukan dengan metode purposive sampling dan sampel yang diperoleh dalam penelitian ini berjumlah 10 perusahaan transportasi darat. Teknik analisa data menggunakan Kolmogorov Sminorv test dan Paired Sample t-test. Hasil penelitian ini menunjukkan bahwa tidak terdapat perbedaan signifikan abnormal return saham sebelum dan sesudah pengumuman penurunan harga BBM. Tetapi terdapat perbedaan signifikan trading volume activity saham sebelum dan sesudah pengumuman penurunan harga BBM.
\end{abstract}

Kata Kunci : Pengumuman Penurunan BBM, Abnormal Return, Trading Volume Activity, Event Study

\section{A. PENDAHULUAN}

Pasar Modal merupakan tempat bertemu antara pembeli dan penjual dengan risiko untung dan rugi. Pasar modal merupakan sarana perusahaan untuk meningkatkan kebutuhan dana jangka panjang dengan menjual saham atau mengeluarkan obligasi (Jogiyanto 2013:29). Pasar modal juga merupakan salah satu penggerak perekonomian suatu negara dimana pasar modal dapat dijadikan tolak ukur dari perekonomian negara tersebut (Lawrence, 2013).Kestabilan perekonomian suatu negara sangat berpengaruh terhadap kinerja di dalam pasar modal negara tersebut, begitu pula dengan pasar modal di Indonesia. 
Sebagai salah satu instrumen perekonomian, maka pasar modal tidak terlepas dari pengaruh lingkungan sekitarnya, baik peristiwa yang bersifat mikro ekonomi yaitu keadaan emiten, seperti laporan kinerja, pembagian deviden, perubahan strategis dalam Rapat Umum Pemegang Saham (RUPS) akan menjadi informasi yang menarik bagi para investor di pasar modal. Informasi makro ekonomi sendiri berkaitan dengan kondisi pasar berupa berita politik, kebijakan ekonomi nasional, serta kebijakan yang berkaitan dengan pasar modal (Setyawan, 2006). Informasi - informasi tersebut akan memberikan sinyal bagi para investor dalam pengambilan keputusan investasi sehingga ikut berpengaruh terhadap fluktuasi harga dan volume perdagangan di pasar modal.

Salah satu peristiwa yang sangat berpengaruh terhadap perekonomian Indonesia adalah kebijakan pemerintah unuk menurunkan harga Bahan Bakar Minyak (BBM). Selama tahun 2016 ini sudah terjadi penurunan harga Bahan Bakar Minyak sebanyak dua kali yakni tanggal 5 Januari 2016 dan tanggal 1 April 2016. Pada tanggal 1 April 2016, pemerintah memutuskan penurunan harga premium dan solar bersubsidi, masing - masing sebesar Rp. 500,- per liter. Harga premium sebelumnya Rp. 7.050,- turun menjadi Rp. 6.550,- per liter. Sedangkan harga solar dari sebelumnya Rp. 5.650,- turun menjadi Rp. 5.150,- per liter. Penyesuaian harga Bahan Bakar Minyak (BBM) ini merupakan salah satu kebijakan pemerintahan Jokowi untuk menjaga kondisi fundamental agar harga tetap rendah dan inflasi terjaga. (www.ksp.go.id, 30 Maret 2016). Dengan adanya peristiwa ini, inflasi IHK pada kuartal IV 2016 tetap berada dalam rentang target inflasi 4 plus minus 1 persen. Sementara itu IHK per Maret 2016 mengalami inflasi sebesar 0,19 persen. Sehingga inflasi dari Januari - Maret 2016 atau inflasi tahun kalender 2016 mencapai 0,62 persen dan inflasi tahun ke tahun tercatat sebesar 4,45 persen (www.bisniskeuangan.kompas.com, 8 April 2016).

Perubahan harga Bahan Bakar Minyak (BBM) tidak hanya mempengaruhi kehidupan masyarakat kecil tetapi juga mempengaruhi kelangsungan hidup dunia usaha. Perubahan harga Bahan Bakar Minyak (BBM) akan mempengaruhi biaya operasional dan produksi di dunia usaha. Peristiwa penurunan harga Bahan Bakar Minyak memberikan dampak positif pada harga saham di Bursa Efek Indonesia, khususnya perusahaan transportasi yang sangat membutuhkan Bahan Bakar Minyak dalam mendukung operasionalnya.

Trading Volume Activity saham dan Abnormal Return merupakan variabel indikator transaksi perdagangan efek di bursa efek yang dapat diamati dan diteliti untuk melihat reaksi pasar modal terhadap pengumuman penurunan Bahan Bakar Minyak.Fluktuasi volume perdagangan saham merupakan suatu indikator yang penting untuk mempelajari tingkah laku pasar dalam melakukan aksi jual beli di pasar modal. Adanya keberadaan sebuah informasi tersebut akan mempengaruhi investor dalam melakukan transaksi jual beli saham.

Dampak dari suatu peristiwa terhadap pasar saham dapat dipelajari melalui penelitian event study. Event study dapat digunakan untuk menguji kandungan informasi (information content) dari suatu pengumuman dan dapat juga digunakan untuk menguji efisiensi pasar bentuk setengah kuat (Jogiyanto, 2013:585).

Penelitian ini dilakukan untuk mengetahui pengaruh pengumuman penurunan harga Bahan Bakar Minyak tanggal 1 April 2016 terhadap terhadap investasi saham yang diproksikan terhadap abnormal return dan trading volume activity.

Berdasarkan latar belakang diatas maka yang menjadi rumusan masalah dari penelitian ini adalah: 1) Apakah terdapat perbedaan yang signifikan Abnormal Return saham pada Perusahaan Transportasi Darat yang terdaftar di Bursa Efek Indonesia 
sebelum dan sesudah pengumuman penurunan harga BBM pada tanggal 1 April 2016 dan 2) Apakah terdapat perbedaan signifikan Trading Volume Activity saham pada Perusahaan Transportasi Darat yang terdaftar di Bursa Efek Indonesia sebelum dan sesudah pengumuman penurunan harga BBM pada tanggal 1 April 2016.

\section{B. LANDASAN TEORI}

Signaling theory adalah teori yang yang melihat tanda-tanda tentang kondisi yang menggambarkan suatu perusahaan.Signaling theory menekankan kepada pentingnya informasi yang dikeluarkan oleh perusahaan terhadap keputusan investasi pihak di luar perusahaan. Informasi merupakan unsur penting bagi investor dan pelaku bisnis karena informasi pada hakekatnya menyajikan keterangan, catatan atau gambaran baik untuk keadaan masa lalu, saat ini maupun keadaan masa yang akan datang bagi kelangsungan hidup suatu perusahaan dan bagaimana pasaran efeknya. Informasi yang lengkap, relevan, akurat dan tepat waktu sangat diperlukan oleh investor di pasar modal sebagai alat analisis untuk mengambil keputusan.

Hartono (2013) dalam Lestari (2015) menjelaskan bahwa informasi yang dipublikasikan sebagai suatu pengumuman akan memberikan signal bagi investor dalam pengambilan keputusan investasi. Sinyal perubahan dapat dilihat dari reaksi saham.Reaksi tersebut dapat berupa reaksi positif dan reaksi negatif.Reaksi pasar ditunjukkan dengan adanya perubahan volume perdagangan saham.

Pada waktu informasi diumumkan dan semua pelaku pasar sudah menerima informasi tersebut, pelaku pasar terlebih dahulu menginterpretasikan dan menganalisis informasi tersebut sebagai signal baik (good news) atau signal buruk (bad news). Jika pengumuman informasi tersebut sebagai signal baik bagi investor, maka terjadi perubahan dalam volume perdagangan saham.

Sunariyah (2000:5) menyebutkan pasar modal adalah tempat pertemuan antara penawaran dengan permintaan surat berharga. Di pasar modal, para pelaku pasar yaitu individu - individu atau badan usaha yang mempunyai kelebihan dana (surplus funds) melakukan investasi dalam surat berharga yang ditawarkan oleh emiten. Sebaliknya, di tempat itu pula perusahaan (entities) yang membutuhkan dana menawarkan surat berharga dengan cara listing terlebih dahulu pada badan otoritas di pasar modal sebagai emiten.

Menurut Jogiyanto (2013:585) studi peristiwa (event study) merupakan studi yang mempelajari reaksi pasar terhadap suatu peristiwa (event) yang informasinya dipublikasikan sebagai suatu pengumuman.Event study dapat digunakan untuk menguji kandungan informasi (information content) dari suatu pengumuman dan dapat juga digunakan untuk menguji efisiensi pasar bentuk setengah kuat.

Tandelilin (2010) dalam Gratias (2015) menjelaskan bahwa pasar dapat dikatakan efisien jika harga - harganya sekuritasnya tidak terlalu menyimpang dari nilai instriksiknya..Nilai instrinsik yang dimaksud adalah informasi yang terdapat dalam laporan keuangan perusahaan penerbit saham.

Abnormal return atau excess return merupakan kelebihan dari return yang sesungguhnya terjadi terhadap return normal. Return normal merupakan return ekspektasi (retur yang diharapkan investor). Dengan demikian return tidak normal (abnormal return) adalah selisih antara return sesungguhnya terjadi dengan return ekspektasi, dengan rumus sebagai berikut (Jogiyanto, 2013)

Volume perdagangan saham adalah banyaknya jumlah lembar saham yang diperdagangkan dalam satu hari perdagangan.Perubahan volume perdagangan saham di 
pasar modal menunjukkan aktivitas perdagangan saham di bursa dan mencerminkan keputusan investor. Menurut Priandari (2006, dalam Lestari 2015) volume cenderung akan meningkat saat harga mengalami penurunan maka pasar diindikasikan dalam keadaan bearish (lesu). Ketika volume cenderung meningkat selama harga mengalami kenaikan maka pasar diindikasikan dalam keadaan bullish (optimis).Ketika volume cenderung mengalami penurunan selama harga jual mengalami penurunan maka pasar dalam keadaan bullish, dan ketika volume cenderung mengalami penurunan selama harga mengalami kenaikan maka pasar dalam keadaan bearish.

Volume perdagangan saham diukur dengan menggunakan pengukuran perubahan likuiditas saham.Secara umum likuiditas saham diukur dengan menggunakan Trading Volume Activity (TVA). TVA menggambarkan porsi saham yang diperdagangkan terhadap total jumlah saham perusahaan yang beredar pada suatu waktu tertentu.

\section{Hipotesa}

Hipotesa dalam penelitian ini adalah sebagai berikut :

$\mathrm{H}_{\mathrm{a} 1}=$ Terdapat perbedaan Abnormal Return yang signifikan pada perusahaan transportasi darat sebelum dan sesudah terjadinya pengumuman penurunan harga BBM tanggal 1 April 2016

$\mathrm{H}_{\mathrm{a} 2}=$ Terdapat perbedaan Trading Volume Activity (TVA) yang signifikan pada perusahaan transportasi darat sebelum dan sesudah terjadinya pengumuman penurunan harga BBM tanggal 1 April 2016.

\section{METODOLOGI PENELITIAN}

Jenis penelitian ini adalah penelitian event study .Peristiwa yang diuji dalam penelitian ini adalah peristiwa pengumuman penurunan harga BBM pada tanggal 1 April 2016. Informasi dari pengumuman perubahan harga BBM akan diuji pengaruhnya terhadap investasi saham yang diproksikan terhadap abnormal return dan trading volume activity.

Dalam penelitian ini menggunakan periode pengamatan (event study) selama 14 hari di sekitar tanggal pengumuman, yaitu 7 hari sebelum tanggal pengumuman (pre event window) dan 7 hari setelah tanggal pengumuman (post event period). Pengambilan periode selam 14 hari dilakukan untuk menghindari confounding effect dengan adanya peristiwa lain, karena pengambilan periode yang terlalu panjang (lebih dari 7 hari) ataupun terlalu pendek (kurang dari 7 hari) akan menyebabkan pengaruh bias.

Penelitian ini menggunakan metode dengan pendekatan Kuantitatif. populasi dalam penelitian ini adalah perusahaan transportasi yang terdaftar dalam indeks sektoral yakni sektor Infrastruktur, Utilitas dan Transportasi sub sektor Transportasi di Bursa Efek Indonesia periode 2016.Metode dalam pengambilan sampel dalam penelitian ini adalah menggunakan purposive sampling.Adapun kriteria yang digunakan untuk memilih sampel dalam penelitian ini antara lain :

1. Perusahaan - perusahaan tersebut telah terdaftar pada kelompok Indeks Sektoral Bursa Efek Indonesia yakni sektor Infrastruktur, Utilitas dan Transportasi sub sektor Transportasi periode April 2016 khususnya transportasi darat.

2. Perusahaan tidak melakukan Corporate Action seperti pengumuman deviden, pengumuman laba, right issue, stock split, dan lain - lain selama periode penelitian. Hal ini dilakukan agar tidak terjadi confounding effect yaitu reaksi pasar terhadap peristiwa lain yang berdekatan dengan peristiwa yang sedang diteliti. 
3. Memiliki data yang lengkap yang diperlukan dalam penelitian ini yakni data harian harga saham, data harian volume perdagangan saham dan data harian jumlah saham beredar perusahaan.

Data yang digunakan dalam penelitian ini merupakan data sekunder, yaitu data diperoleh atau dikumpulkan dari penelitian orang lain atau sumber yang telah dipublikasikan. Adapun sumber data yang akan diolah dalam analisis penelitian ini adalah:

1. Data harian harga saham dan data harian volume perdagangan saham serta data harian jumlah saham beredar perusahaan selama periode pengamatan diambil dari database Bursa Efek Indonesia (www.idx.co.id).

2. Data harian IHSG selama periode pengamatan, diambil dari database Yahoo Finance (www. finance.yahoo.com)

Variabel -Variabel yang akan diteliti dapat didefinisikan sebagai berikut :

1. Abnormal Return. Abnormal return atau excess return merupakan kelebihan dari return yang sesungguhnya terjadi terhadap return normal. Return normal merupakan returnekspektasi (return yang diharapkan investor). Dengan demikian return tidak normal (abnormal return) adalah selisih antara return sesungguhnya terjadi dengan return ekspektasi. Menghitung abnormal return, yang dihitung dengan mengurangi return sesungguhnya dengan return yang diharapkan dengan formulasi menurut Jogiyanto (2013) adalah $\mathrm{RTN}_{\mathrm{i} . \mathrm{t}}=\mathrm{R}_{\mathrm{i} . \mathrm{t}}-\mathrm{E}\left[\mathrm{R}_{\mathrm{i.t}}\right]$

$\mathrm{RTN}_{\mathrm{i} . \mathrm{t}}=$ Return taknormal (abnormal return) sekuritas ke-i pada periode peristiwa ke-t.

$\mathrm{R}_{\mathrm{i} . \mathrm{t}}=$ return realisasian yang terjadi untuk sekuritas ke-i pada periode peristiwa ke-t

$\mathrm{E}\left[\mathrm{R}_{\mathrm{i} . \mathrm{t}}\right]=$ return ekspektasian sekuritas ke-i untuk periode peristiwa ke $\mathrm{t}$

Adapun untuk mencari return sesungguhnya digunakan rumus :

$\mathrm{R}_{\mathrm{i.t}}=\frac{P_{i . t}-P_{i . t-1}}{P_{i . t-1}}$

Keterangan :

$\mathrm{R}_{\mathrm{i} . \mathrm{t}} \quad=$ return individual saham ke-I pada hari $\mathrm{t}$

$\mathrm{P}_{\mathrm{i} . \mathrm{t}} \quad=$ closing price pada hari $\mathrm{t}$

$\mathrm{P}_{\mathrm{i} . \mathrm{t}-1} \quad=$ closing price pada hari $\mathrm{t}-1$

Sedangkan return yang diharapkan pada periode ke-t digunakan rumus

$\mathrm{E}\left[\mathrm{R}_{\mathrm{i} . t}\right]=\frac{I H S G_{t}-I H S G_{t-1}}{I H S G_{t-1}}$

Keterangan :

$\mathrm{E}\left[\mathrm{R}_{\mathrm{i.t}}\right]=$ return ekspektasian sekuritas i pada hari ke-t

$\mathrm{IHSG}_{\mathrm{t}}=$ IHSG pada hari ke-t

$\mathrm{IHSG}_{\mathrm{t}-1}=$ IHSG pada hari ke $\mathrm{t}-1$

Menghitung rata - rata return taknormal (average abnormal return) untuk hari ke-t dapat dihitung berdasarkan rata - rata aritmatika sebagai berikut (Jogiyanto,2013):

$\operatorname{RRTN}_{\mathrm{t}}=\frac{\sum_{i=1}^{k} R T N_{i . t}}{k}$

Keterangan :

$\mathrm{RRTN}_{\mathrm{t}}=$ rata - rata return taknormal (average abnormal return) pada hari ke-t

$\mathrm{RTN}_{\mathrm{i} . \mathrm{t}}=$ return taknormal (abnormal return) untuk sekuritas ke-I pada hari ke-t

$\mathrm{K}=$ jumlah sekuritas yang terpengaruh oleh pengumuman peristiwa 
2. Trading Volume Activity. Trading volume activity (TVA) digunakan untuk melihat perubahan atas likuiditas saham.Trading volume activity dihitung untuk setiap saham dengan membandingkan antara jumlah yang diperdagangkan dengan jumlah saham yang beredar. Menghitung Trading Volume Activity (TVA) masing - masing saham pada periode sebelum dan sesudah peristiwa dengan menggunakan rumus sebagai berikut (Febriyanti dan Rahyuda, 2016) :

$\mathrm{TVA}_{\mathrm{i.t}}=\frac{\text { saham perusahaan } \mathrm{i} \text { yang diperdagangkan pada waktu } k e-t}{\text { saham perusahaan } \mathrm{i} \text { yang beredar pada waktu } k e-t}$

Keterangan :

TVA $_{i . t}=$ volume perdagangan saham perusahaan I pada waktu ke- $\mathrm{t}$

Untuk menghitung rata - rata volema perdagangan untuk seluruh perusahaan sampel selama event window dengan men nakan rum dibawah ini:

$$
\text { Nim }=\frac{\sum_{i=1}^{n} T V A}{n}
$$

$$
\begin{aligned}
& \text { merangan : }
\end{aligned}
$$

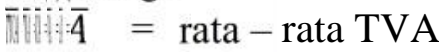

$$
\begin{aligned}
& \text { NDA: } \mathrm{A}=\text { volume perdagangan saham perusahaan } \\
& \mathrm{n} \quad=\text { total sampel }
\end{aligned}
$$

\section{HASIL PENELITIAN DAN PEMBAHASAN \\ Hasil Uji Normalitas}

Uji normalitas dalam penelitian ini menggunakan Kolmogrov Sminorv Test, dimana perhitungannya dilakukan dengan menggunakan program Statistical Package for Social Science (SPSS) 16.0 for windows. Dasar pengambilan keputusan uji Kolmogrov Sminorv Test bahwa data dianggap normal jika Asymp. Sig 2-Tailed>0,05

\begin{tabular}{|c|c|c|c|}
\hline \multirow{2}{*}{$\mathrm{N}$} & & Sebelum & sesudah \\
\hline & & 7 & 7 \\
\hline \multirow{2}{*}{$\begin{array}{l}\text { Normal } \\
\text { Parameters }^{\mathrm{a}}\end{array}$} & Mean & -.0042177 & -.0028804 \\
\hline & Std. Deviation & .01513883 & .01173072 \\
\hline \multirow{3}{*}{$\begin{array}{l}\text { Most } \\
\text { Extreme } \\
\text { Differences }\end{array}$} & Absolute & .251 & .204 \\
\hline & Positive & .158 & .204 \\
\hline & Negative & -.251 & -.174 \\
\hline \multicolumn{2}{|c|}{ Kolmogorov-Smirnov Z } & .663 & .539 \\
\hline \multicolumn{2}{|c|}{ Asymp. Sig. (2-tailed) } & .772 & .933 \\
\hline
\end{tabular}
dan data dikatakan tidak normal jika Asymp. Sig 2-Tailed< 0,05.

Tabel 1: Hasil Uji Normalitas Rata - Rata Abnormal Return

a. Test distribution is Normal.

\begin{tabular}{|c|c|c|c|}
\hline & & Sebelum & sesudah \\
\hline $\mathrm{N}$ & & 7 & 7 \\
\hline \multirow{2}{*}{$\begin{array}{l}\text { Normal } \\
\text { Parameters }^{\mathrm{a}}\end{array}$} & Mean & .0068757 & .0024571 \\
\hline & Std. Deviation & .00372873 & .00072800 \\
\hline \multirow{2}{*}{$\begin{array}{l}\text { Most Extreme } \\
\text { Differences }\end{array}$} & Absolute & .208 & .225 \\
\hline & Positive & .208 & .225 \\
\hline
\end{tabular}

Sumber : Data diolah dari SPSS 16.0

Tabel 2: Hasil Uji Normalitas Rata - Rata Trading Volume Activity 


\begin{tabular}{lrr}
\hline \multicolumn{1}{c}{ Negative } & -.188 & -.138 \\
\hline Kolmogorov-Smirnov Z & .551 & .595 \\
\hline Asymp. Sig. (2-tailed) & .922 & .871 \\
\hline a. Test distribution is Normal. & & \\
\hline Sumber : Data diolah dari SPSS 16.0 & &
\end{tabular}

Dari hasil pengujian normalitas data pada tabel 4.3 dan tabel 4.4 diperoleh nilai probabilitas (Asymp. Sig 2-Tailed) yang lebih besar daripada $\alpha(0,05)$. Dengan demikian, distribusi nilai Rata - Rata Abnormal Retun dan Rata - Rata TVA sebelum dan sesudah peristiwa penurunan harga BBM adalah normal. Berdasarkan pengujian normalitas data yang memiliki distribusi normal, penelitian ini akan diuji dengan analisis statistik parametrik menggunakan uji Paired Sample t-Test

\section{Pengujian Hipotesis I}

Pengujian hipotesis I dilakukan untuk mengetahui apakah terdapat perbedaan Abnormal Return saham perusahaan transportasi darat sebelum dan sesudah peristiwa pengumuman harga BBM. Hipotesis pertama adalah sebagai berikut :

$\mathrm{H}_{\mathrm{o} 1}$ : Tidak terdapat perbedaan Abnormal Return yang signifikan pada perusahaan transportasi darat sebelum dan sesudah terjadinya pengumuman penurunan harga BBM tanggal 1 April 2016.

$\mathrm{H}_{\mathrm{a} 1}$ : Terdapat perbedaan Abnormal Return yang signifikan pada perusahaan transportasi darat sebelum dan sesudah terjadinya pengumuman penurunan harga BBM tanggal 1 April 2016.

Tabel 3: Hasil Uji Paired Sample t-Test Abnormal Retun Sebelum dan Sesudah Peristiwa Pengumuman Penurunan Harga BBM

\begin{tabular}{lr}
\hline Mean sebelum & $-0,0042177$ \\
\hline Mean sesudah & $-0,0028804$ \\
\hline Df & 6 \\
\hline t hitung & $-0,205$ \\
\hline t tabel & 2,447 \\
\hline Sig. (2-tailed) & 0,844 \\
\hline Sumber : Data diolah dari SPSS 16.0
\end{tabular}

Berdasarkan hasil perhitungan statistik yang diperlihatkan pada tabel diatas, menunjukkan rata - rata abnormal return sebelum peristiwa pengumuman penurunan harga BBM adalah sebesar -0,0042177 dan sesudah pengumuman sebesar -0,0028804, hal ini menunjukkan adanya rata - rata abnormal return sebelum maupun sesudah pengumuman tetapi reaksi investor cenderung reaksi negatif.

Dari hasil tabel diatas menunjukkan bahwa $t_{\text {hitung }}(-0,205)$ berada di dalam daerah penerimaan $\mathrm{H}_{\mathrm{o} 1}\left(-\mathrm{t}_{(\alpha / 2: \mathrm{n}-1)} \leq \mathrm{t} \leq \mathrm{t}_{(\alpha / 2: \mathrm{n}-1)}\right)$ karena $-2,447 \leq-0,205 \leq 2,447$, maka dapat diperoleh keputusan untuk menerima $\mathrm{H}_{\mathrm{o} 1}$ dan menolak $\mathrm{H}_{\mathrm{a} 1}$. Ditinjau dari nilai probabilitasnya dimana Sig. (2-tailed) 0,844 >0,05, mempunyai arti bahwa rata - rata abnormal return sebelum dan sesudah peristiwa pengumuman penurunan harga BBM tidak terdapat perbedaan yang signifikan.

Berdasarkan hasil pengujian diatas, maka diambil kesimpulan bahwa $\mathrm{H}_{\mathrm{o} 1}$ diterima, dimana tidak terdapat perbedaan abnormal return saham perusahaan transportasi darat yang signifikan sebelum dan sesudah peristiwa pengumuman penurunan harga BBM. 


\section{Pengujian Hipotesis II}

Pengujian hipotesis II dilakukan untuk mengetahui apakah terdapat perbedaan Trading Volume Activity saham perusahaan transportasi darat sebelum dan sesudah peristiwa pengumuman harga BBM. Hipotesis kedua adalah sebagai berikut :

$\mathrm{H}_{\mathrm{O} 2}$ : Tidak terdapat perbedaan Trading Volume Activity (TVA) yang signifikan pada perusahaan transportasi darat sebelum dan sesudah terjadinya pengumuman penurunan harga BBM tanggal 1 April 2016.

$\mathrm{H}_{\mathrm{a} 2}$ : Terdapat perbedaan Trading Volume Activity (TVA) yang signifikan pada perusahaan transportasi darat sebelum dan sesudah terjadinya pengumuman penurunan harga BBM tanggal 1 April 2016.

$\begin{array}{cc}\text { Tabel 4: Hasil Uji Paired Sample t-Test Trading Volume Activity (TVA) } \\ \text { Sebelum dan Sesudah Peristiwa Pengumuman Penurunan Harga BBM } \\ \text { Mean sebelum } & 0,0068757 \\ \text { Mean sesudah } & 0,0024571 \\ \text { Df } & 6 \\ \text { t hitung } & 3,075 \\ \text { t tabel } & 2,447 \\ \text { Sig. (2-tailed) } & 0,022\end{array}$

Berdasarkan hasil perhitungan statistik yang diperlihatkan pada tabel diatas menunjukkan rata - rata trading volume activity sebelum peristiwa pengumuman penurunan harga BBM adalah sebesar 0,0068757 dan sesudah pengumuman sebesar 0,0024571 , hal ini menunjukkan terdapat perubahan rata - rata aktivitas volume perdagangan selama periode pengamatan.

Dari hasil tabel diatas menunjukkan bahwa $\left.t_{\text {hitung }} 3,075\right)$ berada di dalam daerah penerimaan $\mathrm{H}_{\mathrm{a} 2}\left(\mathrm{t}<-\mathrm{t}_{(\alpha / 2: \mathrm{n}-1)}\right.$ atau $\left.\mathrm{t}>\mathrm{t}_{(\alpha / 2: \mathrm{n}-1)}\right)$ karena 3,075>2,447, maka dapat diperoleh keputusan untuk menerima $\mathrm{H}_{\mathrm{a} 2}$ dan menolak $\mathrm{H}_{\mathrm{o} 2}$. Ditinjau dari nilai probabilitasnya dimana Sig. (2-tailed) $0,022<0,05$, mempunyai arti bahwa rata - rata trading volume activity sebelum dan sesudah peristiwa pengumuman penurunan harga BBM terdapat perbedaan yang signifikan.

Berdasarkan hasil pengujian diatas, maka diambil kesimpulan bahwa $\mathrm{H}_{\mathrm{a} 2}$ diterima, dimana terdapat perbedaan trading volume activity saham perusahaan transportasi darat yang signifikan sebelum dan sesudah peristiwa pengumuman penurunan harga BBM.

\section{Pembahasan}

\section{Abnormal Return Sebelum dan Sesudah Peristiwa Perubahan Harga BBM tanggal 1 April 2016}

Dalam pasar modal yang efisien seluruh informasi yang relevan yang berkaitan dengan perusahaan yang go public akan tercermin dari harga - harga sahamnya. Munculnya informasi yang baru seperti halnya pengumuman penurunan harga BBM akan dengan segera dipersepsikan oleh investor. Persepsi dari masing - masing investor atas informasi yang diterima tidaklah selalu sama sehingga akan menimbulkan reaksi yang berbeda pula diantara para investor tersebut. Gabungan dari seluruh reaksi dari investor atas informasi baru yang menyangkut suatu saham akan membentuk suatu reaksi pasar atas informasi baru tersebut.

Dalam penelitian ini reaksi pasar yang diuji adalah reaksi pasar di sekitar pengumuman penurunan harga BBM yaitu 7 hari sebelum peristiwa pengumuman dan 7 hari setelah peristiwa pengumuman. Reaksi yang terjadi akan tercermin dari perubahan harga saham yang diukur dengan menggunakan abnormal return dan trading volume 
activity. Dari pengujian hipotesis diatas didapatkan hasil bahwa tidak ada perbedaan signifikan abnormal return sebelum dan sesudah pengumuman penurunan BBM tanggal 1April 2016. Hal ini dapat dilihat dari nilai $t$ hitung lebih kecil dari t tabel $(-0,205$ $<2,447$ ) pada tingkat signifikansi 5\% . selain itu, nilai signifikansi abnormal return sebelum dan sesudah penurunan harga BBM lebih besar dari $\alpha=5 \%(0,844>0,05)$ yang menunjukkan tidak ada perbedaan signifikan antara abnormal return sebelum dan sesudah peristiwa penurunan harga BBM sehingga hipotesis pertama yang menyatakan " Terdapat perbedaan abnormal return yang signifikan pada perusahaan transportasi darat sebelum dan sesudah terjadinya pengumuman penurunan harga BBM tanggal 1 April 2016 " ditolak.

Peristiwa penurunan harga BBM tidak memberi dampak yang signifikan pada perusahaan transportasi darat dikarenakan isu seputar perubahan harga BBM sudah cukup lama beredar di masyarakat. Ditambah dengan seringnya terjadi perubahan harga BBM yang selama kurun waktu 2015 dan 2016 membuat pasar berada dalam kondisi penuh ketidakpastian. Bahkan setelah pengumuman penurunan harga BBM dilakukan oleh pemerintah tidak ada perbedaan abnormal return saham. Dari sini terlihat pelaku pasar cenderung memprediksi akan terjadi perubahan harga BBM yang berulang sesuai dengan harga minyak dunia, sehingga isu perubahan harga BBM yang terpublikasi di media sebelum pengumuman dari pemerintah dipublikasikan beredar luas dan telah diketahui serta dianalisa terlebih dahulu oleh investor.

Ada kemungkinan faktor lain diluar informasi pengumuman kebijakan penurunan harga BBM yang menyebabkan abnormal return tidak berubah signifikan. Faktor faktor tersebut antara lain nilai intrinsik perusahaan tersebut seperti aktiva, pendapatan, deviden dan prospek perusahaan yang dapat mempengaruhi dalam proses penilaian saham selain harga (Sunariyah, 2000:154), selain itu kondisi perekonomian secara makro, kebijakan pemerintah lainnya, kondisi persaingan dan situasi politik juga turut mempengaruhi kebijakan investor dalam menentukan keputusannya.

\section{Trading Volume Activity (TVA) Sebelum dan Sesudah Peristiwa Perubahan Harga BBM tanggal 1 April 2016}

Sedangkan untuk trading volume activity, didapatkan hasil bahwa terdapat perbedaan yang signifikan antara trading volume activity (TVA) sebelum dan sesudah pengumuman penurunan harga BBM.Hal ini dapat dilihat dari nilai t hitung yang lebih besar daripada t tabel $(3,075>2,447)$ pada tingkat signifikansi $5 \%$. Selain itu, nilai signifikansi TVA sebelum dan sesudah pengumuman penurunan harga BBM lebih kecil daripada nilai signifikansi $\alpha=5 \%(0,022<0,05)$ yang menunjukkan bahwa TVA sebelum dan sesudah pengumuman penurunan harga BBM berbeda signifikan. Sehingga hipotesis kedua yang menyatakan " Terdapat perbedaan trading volume activity yang signifikan pada perusahaan transportasi darat sebelum dan sesudah terjadinya pengumuman penurunan harga BBM tanggal 1 April 2016 “ diterima.

Dikarenakan pelaku pasar sudah dapat memprediksi perubahan harga BBM ini maka setelah pengumuman penurunan harga BBM, investor cenderung untuk menunda transaksi.Pelaku pasar belajar dari pengalaman perubahan harga BBM pada tahun tahun sebelumnya dimana pasar akan kembali stabil beberapa saat setelah pengumuman perubahan harga BBM.

\section{E. PENUTUP}

Berdasarkan hasil pembahasan dan analisa terhadap perolehan abnormal return dan trading volume activity saham yang dijadikan sampel di sekitar tanggal 
pengumuman dapat diambil beberapa kesimpulan. Pertama, tidak terdapat perbedaan signifikan abnormal return sebelum dan sesudah pengumuman perubahan harga BBM pada tanggal 1 April 2016, ditunjukkan dengan nilai t hitung lebih kecil dari t tabel ($0,205<2,447)$ pada tingkat signifikansi $5 \%$. Serta nilai signifikansi 0,844 yang lebih besar dari signifikansi 0,05 . Hal ini menunjukkan bahwa tidak terdapat perubahan nilai abnormal return yang berbeda pada periode sebelum dan sesudah peristiwa. Informasi tentang pengumuman perubahan harga BBM sudah dapat diprediksi sebelumnya oleh pasar dikarenakan sudah terlalu seringnya terjadi perubahan harga BBM dalam kurun waktu terakhir ini sehingga mengakibatkan pasar tidak merespon atau tidak bereaksi. Kedua, terdapat perbedaan signifikan trading volume activity sebelum dan sesudah peristiwa pengumuman perubahan harga BBM pada tanggal 1 April 2016, ditunjukkan dengan nilai $\mathrm{t}$ hitung yang lebih besar dari $\mathrm{t}$ tabel $(3,075>2,447)$ pada tingkat signifikansi $5 \%$. Serta nilai signifikansi 0,022 yang lebih kecil dari signifikansi 0,05 . Hal ini menunjukkan bahwa terdapat perubahan volume perdagangan pada periode sebelum dan sesudah peristiwa. Informasi tentang pengumuman perubahan harga BBM sudah dapat diprediksi sebelumnya oleh pasar sehingga pasar merespon atau bereaksi.

Berdasarkan hasil penelitian dan kesimpulan, terdapat beberapa saran. Pertaman, bagi perusahaan agar selalu mengamati perubahan harga saham, sehingga apabila terkena dampak kebijakan pemerintah, perusahaan dapat segera mengambil keputusan untuk mengantisipasi hal tersebut.Perusahaan juga harus dapat meningkatkan kinerja semaksimal mungkin, sehingga dalam keadaan apapun perusahaan dapat menaikkan nilai perusahaan dimata investor. Kedua, bagi investor diharapkan mempertimbangkan segala keputusan yang diambil terkait dengan investasi dalam menyikapi informasi yang dipublikasikan.Investor tidak perlu terlalu panik, karena informasi yang beredar belum tentu mencerminkan nilai dari suatu perusahaan. Investor tidak perlu tergesa - gesa melakukan aksi jual beli, lebih baik menerapkan strategi wait and see dengan tujuan bisa mengamati perkembangan yang terjadi setelah keputusan perubahan harga BBM oleh pemerintah. Investor juga diharapkan lebih meningkatkan kepekaan dalam menyerap dan mengelola informasi yang beredar di pasar. Dan bagi peneliti selanjutnya disarankan untuk menggunakan metode perhitungan yang lain seperti mean adjusted model dan market model.

\section{DAFTAR PUSTAKA}

Anoraga, Pandji dan Pakarti Piji. 2001. Pengantar Pasar Modal. Edisi Revisi. Semarang: Rineka Cipta.

Algifari, 2003.Statistika Induktif. Edisi Kedua. Yogyakarta : UPP AMP YKPN

Andarini, Diah.2015. Analisis Reaksi Pasar Modal terhadap Perubahan Harga BBM (Event Study Kenaikan dan Penurunan Harga BBM pada Perusahaan Food and Beverages yang terdaftar di Bursa Efek Indonesia).Fakultas Ekonomi dan Bisnis Universitas Brawijaya.

Febriyanti, Shinta dan Henny Rahyuda.2016. Pengaruh Pengumuman Perubahan Harga BBM Awal Pemerintahan Jokowi - JK Terhadap Reaksi Pasar Modal Indonesia. E-Jurnal Manajemen Unud, Vol. 5, No.2,(2016)838-869

Gratias, Deo. 2015. Pengaruh Peristiwa Kenaikan Harga Bahan Bakar Minyak (BBM) pada Abnormal Return Saham Industri Transportasi di Bursa Efek Indonesia. Skripsi Sarjana Ekonomi Fakultas Ekonomi dan Bisnis Universitas Udayana. 
Indriantoro, Nur Dan Bambang Supomo. 2014. Metodologi Penelitian Bisnis Untuk Akuntansi \& Manajemen.Edisi Pertama, Yogyakarta: BPFE.

Jogiyanto, Hartono. 2013. Teori Portofolio dan Analisis Investasi Edisi Kedelapan. Yogyakarta: BPFE.

Kuncoro, Mudrajad. 2009. Metode Riset untuk Bisnis \& Ekonomi. Edisi Ketiga. Jakarta: Erlangga.

Laksana, Agung. 2014. Pengaruh Kenaikan Harga Bahan Bakar Minyak Bersubsidi Tahun 2013 terhadap Abnormal Return Saham dan Trading Volume Activity Saham pada Perusahaan yang masuk dalam Indeks LQ-45. Skripsi Sarjana Ekonomi Universitas Negeri Yogyakarta.

Lawrence, Steven Sugiarto. 2013. Pengaruh Variabel Makro Ekonomi Dan Harga Komoditas Terhadap Indeks Harga Saham Gabungan Di Indonesi. Finesta, Vol.1, No.2, (2013)18-23.

Lestari, Ratna Desy. 2015. Analisis Pengaruh Pengumuman Perubahan Harga BBM terhadap Abnormal Return dan Trading Volume Activity.Skripsi Sarjana Ekonomi Fakultas Ekonomi Universitas Negeri Semarang.

Ningsih, Ervina Ratna dan Dwi Cahyaningdyah. 2014. Reaksi Pasar Modal Indonesia terhadap Pengumuman Kenaikan Harga BBM 22 Juni 2013. E-Jurnal Manajemen .Unnes, MAJ 1 (3) (2014) http://journal.unnes.ac.id

Ramadhan, Farid Siliwangi. 2014. Pengaruh Kenaikan Harga Bahan Bakar Minyak (BBM) Tahun 2013 Terhadap Investasi Saham (Event Study Saham pada Perusahaan Otomotif dan Komponen yang Terdaftar di Bursa Efek Indonesia).

Sekaran, Uma. 2006. Research Methods For Business. Edisi Empat. Jakarta: Salemba Empat.

Setyawan, St Tri Adi. 2006. Analisis Reaksi pasar Modal terhadap Kenaikan Harga BBM (Studi Kasus: di Bursa Efek Jakarta untuk Saham-saham LQ 45). Magister Manajemen Universitas Diponegoro Semarang.

Sunariyah.2000. Pengantar Pengetahuan Pasar Modal Edisi Kedua. Yogyakarta: UPP AMP YKPN.

Suarjana, I Wayan. 2011. Pengaruh Kebijakan Pemerintah Dalam Menurunkan Harga Bahan Bakar Minyak Terhadap Reaksi Pasar Saham di Bursa Efek Indonesia. Tesis Program Studi Manajemen, Program Pascasarjana Universitas Udayana Denpasar.

Suparsa, I Made Joni dan Ni Made Dwi Ratnadi.2014.Perbedaan Abnormal Return dan Trading Volume Activityatas Pengumuman Kenaikan Harga BBM.E-Jurnal Akuntansi Universitas Udayana 7.2 (2014):382-389

Suryanto.2015.Analysis Abnormal Return Before and After The Announcement of Investment Grade Indonesia. European Centre for Research Training and Development UK(www.ejournals.org), Vol.3 No.1 (2015)11-23

Suwardjono. 2005. Teori Akuntansi Perekayasaan Pelaporan Keuangan. Edisi Ketiga. Yogyakarta: BPFE.

Sugiyono, 2010.Metode PenelitianPendidikan Pendekatan Kuantitatif, Kualitatif dan $R \& D$. Bandung: Alfabeta.

Undang - Undang Republik Indonesia No. 8 tahun 1995 tentang Pasar Modal

Trihendradi, Cornelius.2005. Step by Step SPSS 13 Analisis Data Statistik. Yogyakarta: Andi

http://www.bisniskeuangan.kompas.com,

http://www.ksp.go.id, 
http://www.finance.yahoo.com

http://www.idx.co.id

http://www.sahamok.com

http://duniainvestasi.com

http://www.britama.com 